\title{
Anthrovision
}

Vaneasa Online Journal

$2.1 \mid 2014$

Anthropologie et Numérique

\section{Indigenous media: from transference to appropriation}

Indigenous video in Latin America and processes of visual presentation of self and ethnicity

\section{Laura Cardús i Font}

\section{(2) OpenEdition \\ Journals}

Electronic version

URL: http://journals.openedition.org/anthrovision/668

DOI: 10.4000/anthrovision.668

ISSN: 2198-6754

Publisher

VANEASA - Visual Anthropology Network of European Association of Social Anthropologists

\section{Electronic reference}

Laura Cardús i Font, «Indigenous media: from transference to appropriation », Anthrovision [Online],

2.1 | 2014, Online since 24 September 2014, connection on 19 April 2019. URL : http://

journals.openedition.org/anthrovision/668; DOI : 10.4000/anthrovision.668

This text was automatically generated on 19 April 2019

(c) Anthrovision 


\title{
Indigenous media: from transference to appropriation
}

Indigenous video in Latin America and processes of visual presentation of self and ethnicity

\author{
Laura Cardús i Font
}

\section{AUTHOR'S NOTE}

This article stems from the research made in Chiapas, Mexico, from 2005 to 2007, for my $\mathrm{PhD}$ dissertation "The power of looking at oneself" (unpublished). I have to thank Emilie Delcourt for her support in editing my English.

1 This article aims to provide a short review of the so-called indigenous media projects in Latin America, focusing on describing the Mexican context and the case of audiovisual media. Mexico is a good example to understand the role of the indigenist ${ }^{1}$ institutions and policies in the birth and development of such initiatives. It is also useful to illustrate the processes of appropriation of the media by local and non-governmental organisations and individuals.

2 The movement of indigenous media is linked to various social, political and academic movements that developed around the globe from the 1970s until today. Regarding the different countries, the hatching of such initiatives is related to affirmative policies stemming from the Civil Rights movements, such as in the US, or to indigenist policies, as it happened in Brazil or Mexico. These policies were situated in a very specific socioeconomic world frame and were compassed by several intellectual waves, with a central role of anthropologists, in the case of Mexico, in the construction and reinforcement of ethnic classificatory categories with theoretical justifications.

But, how can we delimit the phenomenon of indigenous media? Some authors such as Wilson and Stewart (2008) define it as the "forms of media expression that are conceptualized, produced and/or created by indigenous peoples across the globe". Therefore, the participation of members of indigenous groups would be a distinctive 
criterion. However, by observing its practice, we realise that this is not an exclusive criterion, as the production of such media is generally a multicultural process, as the same authors also include. On top of that, ethnic belonging is not a simple question, but the delimitations of the category "indigenous will not be discussed in this article. Going back to defining indigenous media, to complete the picture, we can take the definition of Spitulnik who considers that the term "indigenous media" covers a "wide spectrum of media phenomena, ranging from community owned and operated radio, television and video operations to locally produced programs that appear on national television" (2008: 304). She also quotes Ginsburg, in considering them as including various media-related activities of minority indigenous peoples, particularly those understanding themselves as "First Nations" or "Fourth World People" dominated by encompassing states (Íbid: 305).

4 Another definition is given by, the Coordinadora Latinoamericana de Cine y Comunicación de los Pueblos Indigenas (CLACPI) ${ }^{2}$, which defines indigenous cinema and video including "the works and the producers as long as they have a strong compromise to give a dignified voice and vision of knowledge, culture, projects, claims, achievements and struggles of indigenous peoples. (...) Put another way, the indigenous film and video comes with a powerful tool for promoting self-expression and strengthen the authentic development of peoples." ${ }^{3}$ According to this approach, then, what would define a film as "indigenous cinema" or "indigenous video" would be its goals, not only its subject or the ethnic belonging of the people behind it. To properly understand the development of indigenous media, though, it is crucial to be aware of the context in which they appeared.

When talking about indigenous peoples it is needless to say that, while they have been the objects of study par excellence for anthropologists, they have also been historically represented as others and their voices and points of vision have been mostly ignored for several reasons. A very appealing account of this is gathered in the works of Theresa Harlan, especially in her article "Adjusting the Focus for an Indigenous Presence", where the author gives a critical analysis on the presence of Indians in the photographs shot by tourists, anthropologists and artists, and gives a few examples of artistic expression by indigenous authors regarding this fact (as, for instance, the series "Indian Photographing Tourist Photographing Indian" by Zig Jackson). Also the documentary film "Reel Injun" (N. Diamond, 2009) is a good example of how North-American natives have been represented in more than 400 commercial movies, often stressing the most exotic and, often, fantastic traits of their cultures.

6 In spite of the misrepresentation of the aborigines' image, the role of indigenous informants is clearly relevant for the building of ethnographic texts and has a fundamental influence in deciding which elements from a culture are anthropologically meaningful. One example of this is the work of George Hunt, who was a research assistant and translator for Franz Boas and Edward S. Curtis among the Kwakiutl. He is considered an important contributor of the building of the Kwakiutl ethnographic entity, and played a central role in the production of Curtis's 1914 movie, In the Land of the Head Hunters. Hunt was key in connecting the natives and the ethnographers, and his role went beyond the work of an interpreter or an assistant, becoming an anthropological creator (Russell, 1999). Generally, though, the native's point of view is not explicitly shown in either anthropological texts or in the mass media. Thus, an audiovisual text that became a means of expression of the situated knowledge of these social actors could allow us to apprehend a universe that has been invisible and manipulated from a Western point of view. 
7 Taking into consideration the pioneering works of Jean Rouch (Les Maitres Fous, 1955; Moi un noir, 1958; Chrónique d'un eté, 1960) and of Sol Worth and John Adair with the Navajo (1972), we can understand that anthropology and ethnographic cinema have made efforts towards the goal of getting the other's point of view, understanding that it would give us a unique chance to comprehend the life experience and cosmology of the groups under study. The fact of handing the camera to the hands and the eyes of the traditional objects of study could, in a way, break the differentiation among the authority and the social actors, taking advantage of the fact that the informants become para-ethnographers. Therefore, this would help clarifying that the construction of knowledge is a dialogical process.

8 By describing these we cannot forget that, it is not only by the grace of the action of benevolent anthropologists that the camera has ended up on the hands of the natives. In the 21st century, communication technologies are spreading all around the globe, and are cheaper and accessible to more and more people. Especially young people who have been born in the Digital Age, and are having more and more access to a cell phone and an Internet connection, are a growing reality in non-Western nations. Access to camcorders is not so pervasive, but the digital visual culture that arrives through cinemas, TV channels and the Internet is also providing an extra field of expression and communication to groups that have been historically subordinated. The indigenous presence in the World Wide Web and in the networks of exchange of information and images is also clear and growing (Monasterios, 2003).

\section{Indigenous emergency and the media}

Since the 1970s and, especially, from the 1980s on, the existence of indigenous peoples has been linked to cultural and political fights, surrounding indigenous ethnicity with a political aura. José Bengoa described the phenomenon of Indigenous Emergency as the "... Existence of a new identity discourse, that is to say, a 're-invented Indigenous culture'. (It is) a urban reading of the Indigenous tradition, done by the Indigenous peoples themselves, according to their interests and goals. That is why it is a discourse about ethnic identity deeply rooted in tradition, but with the capability of getting out of it and dialoguing with modernity." (2000: 128). As the UN's Commission expressed in their Report on the Discrimination of Minorities in 1986, indigenous peoples have to be defined by their historical and territorial continuity with pre-colonial societies, and by their clear differentiation from the ruling groups in the country they inhabit. According to the Report ${ }^{4}$, self-identification is a basic feature for defining indigenous peoples, and the fact that they work to preserve and transmit their identity, their land and their cosmology. Observing the uses of indigenous media (specially video and the Internet), we can assume that media technologies play a central role in the process of preserving -or re-adapting- traditions, cosmologies and languages, as well as of transmitting them to the future generations.

Leaving aside all the aesthetic and artistic facets of indigenous creations (approached by Leuthold, 1998), an audiovisual production created by members of indigenous groups would provide pieces of information that have been either omitted or distorted by the official indigenist discourses ${ }^{5}$ generated in the last century. As a general feature, we can say that indigenous productions situate the reality of indigenous citizens within contemporary societies as having history, political agency and their own meanings from the inside, from the lived experience and unique cosmovision. Thus, they are a central 
tool for indigenous social and cultural movements, and a clear consequence of the rising of these movements. Quoting the anthropologist Nora Muntañola (2004), when referring to Mexican indigenous video: "Unlike the indigenous film and ethnographic documentary made by Indian or white directors of the National Indigenista Institute, who have shown most indigenous peoples with a patronizing look like the poorest and the most exotic, the new Indian cinema looks for authenticity and respect, without flattening life and with room for change and intercommunication."

What we can consider "indigenous productions" are made with various aims and have diverse purposes. Many of them are created for inner or local audiences, whereas many others are envisioned for an external one, whether in universities, festivals and other distribution channels. The distribution is one of the key issues affecting the impact of the messages generated in these audiovisuals, and it puts into question its power as transmitters of contra-hegemonic messages. This has already put on the table in several CLAPCI declarations regarding the challenges that indigenous cinema and video have to face ${ }^{6}$.

Some of the materials have been created for communication within the community or among various neighbouring or national ethnic groups or social organizations. Others have been made with the aim of transmitting messages or information to a foreign population or to international institutions. Regarding the different uses of indigenous video, the classification made by Cristina Propios (2002: 581) is a useful one and applies to most of the productions analysed for this research ${ }^{7}$. Thus, we could speak of the following categories: videos for the maintenance of historical memory; educational videos; video reports and informative videos.

The first category includes all those works made to keep a record of important events or cultural practices of a group. When asking about the power of indigenous video among its users, this function is one of the most highlighted, as a means of keeping an image of people or customs that have disappeared. It is also often considered as a means of increasing young people's interest for local traditions. For these reasons, this characteristic of indigenous media is the one that is most appreciated by the local recipients. 


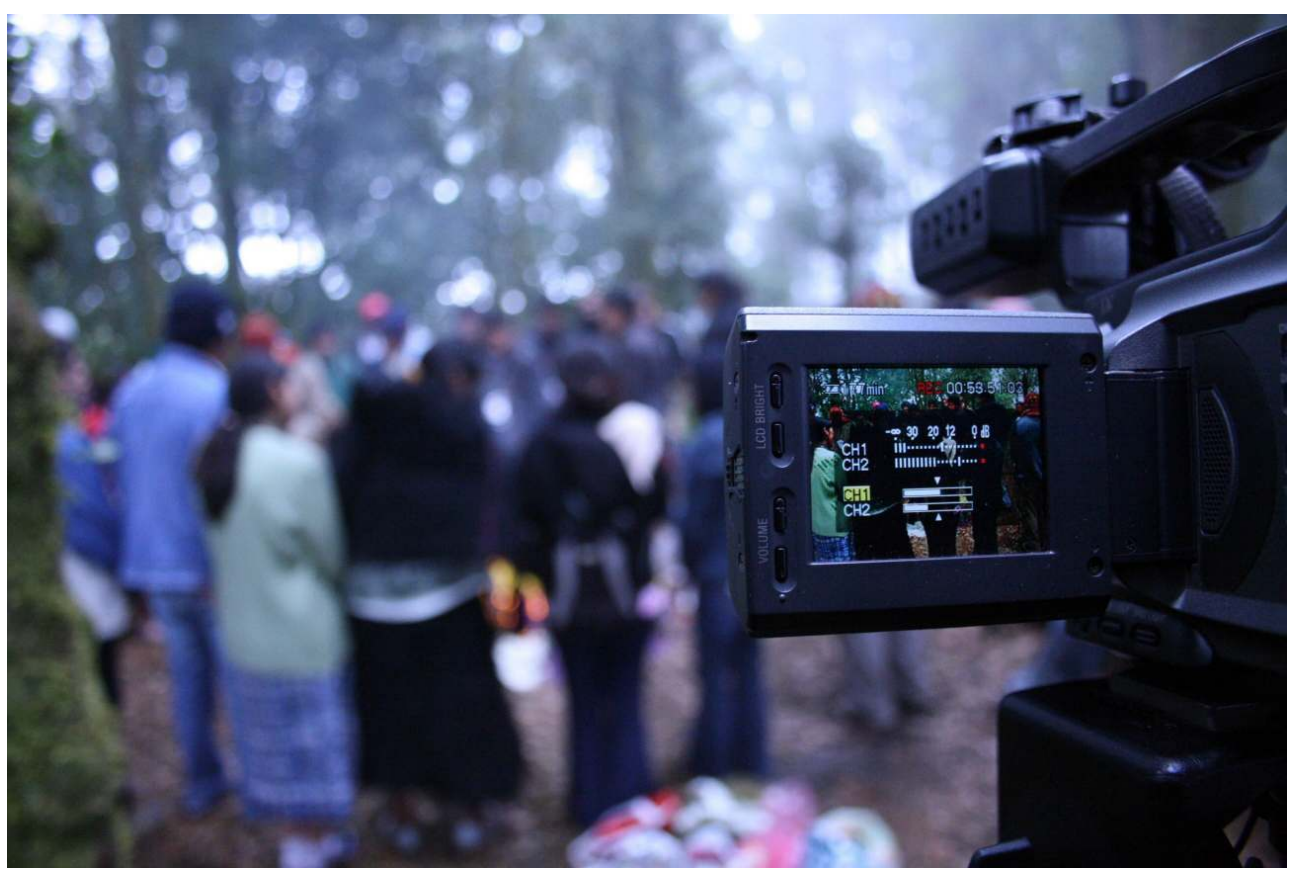

LAURA CARDÚS, 2007

The second category comprises all the materials made either for the general public or for children in a learning environment. Within these productions we find those made using educational formats, such as cartoon animations made to transfer the local history and legends, or to teach a native language. Also, videos made to promote a certain health practice or as a prevention tool from external dangers. This is linked with the videos included in the third category. The reclaiming productions can include testimonials of aggressions towards people, their rights or their communal resources. They are used not only within national or international advocacy processes, but also within the networks of groups and communities, to put pressure in the case of internal power abuses. The need for this kind of material was the initial trigger to begin training local cameramen and women to become "communitarian communicators", instead of using images and testimonials produced by foreign journalists. Finally, informative videos are those that are produced to spread information about the activities of an organization or the use of a technology, for instance, as a ways of connecting with other groups or institutions and exchange knowledge. These videos can be used as a means of creating links or gaining support, and also of obtaining funds from international organizations, i.e.: networking.

What becomes evident and useful for anthropology is that, disregarding the origin and aims of these productions, they have an enormous ethnographic value. Videos become a sort of collective journal of the producers, which helps to analyse the content of the messages that, allegedly, "provide audiences with ways of seeing and interpreting the world, ways that ultimately shape their very existence and participation within a given society" (Spitulnik, 1993: 294, referring to the focus of British Cultural Studies). At the same time, these productions are a basis to study "the culture of media production, as well as the political economy and social history, and the various practices of media consumption that exist in any given society" (Íbid: 295). Indigenous media is surrounded, as any other production of images, by activities and social relationships that tell us how 
representations are built within a specific context. Social actors that participate in an audiovisual production negotiate meanings actively (regarding ethnicity, the concept of person or the traditions) as well as do their audiences when watching and reacting to the audiovisual messages. This negotiation, which would be difficult to discern in other social situations, is clearly reflected during the filming, editing and screening processes. It may sound tautological, but visual productions provide us with a very visual reflection of reality.

Indigenous video, parallel to what ethnographic cinema does, is aimed towards mutual understanding among groups that are spatially and culturally separated. On top of that though, as Ginsburg (1991) already pointed out, the groups involved in these productions work for a mediation across historical, geographical and temporal breakages. That is why historical colonial abuse is the starting point for indigenous media in their most active points: North America, Australia and the Amazon Basin. Which does not mean, though, that the processes of self-representation and media appropriation are necessarily autonomous or independent from hegemonic institutions. As it will be explained below, the political dialogue always exists between some specific governmental policies and the alternative projects that appeared later in several countries with an indigenous presence. As well as the semantic content of the media productions made by indigenous peoples is always engaged in a dialogue between hegemonic messages on ethnicity and subaltern messages built from the margins.

Self-representation with an audiovisual support provides pieces of alternative information (in comparison with messages built from the mass media), which can help overcome certain social stigma or inoculate them with a positive perspective. Having their own audiovisual records allow individuals and groups to build and represent themselves as people with history and agency, and can be a way to construct a sense of common pride and belonging. Several practical examples of the use of indigenous video as a tool for social transformation are gathered in the films of the project Video nas Aldeias ; for instance, we can watch how members from tribes that are geographically separated recognise each other as "brothers", finding common traits in their languages or cultural practices. But films are not only useful to create virtual communities and to built and strengthen social networks, but also to recuperate or to adapt, reinventing, cultural practices that have been lost in the process of cultural contact. Put in another way: video processes contribute to the creation of a modern political ethnicity within the contemporary world, with new meanings, new practices and new discourses.

\section{Indigenous media around the World and in the Americas}

The first audiovisual initiatives in Western countries that had a focus on native peoples were set in Canada and Australia using the broadcasting through satellite technologies of general TV contents to groups that had been historically isolated. In Australia, from 1970 to 1990 , the government set up the Special Broadcasting Service, which includes radio and television aimed at the promotion of multiculturalism (Cunningham Et al., 2000). Aboriginal groups started demanding their place within the television networks, to spread the fight for conservation and promotion of their original languages and cultures (Michaels, 1986; Roth and Ginsburg, 2003, all quoted by Wilson and Stewart, 2008: 4). In this way, governmental projects began to boost the presence of contents related to 
indigenous topics and to propitiate the audiovisual education of indigenous people so as to promote audiovisual productions. During the 1980s, the North American anthropologist Eric Michaels studied the impact of national Australian TV on the indigenous population. During his research he contributed to the creation of the Warlpiri Media Association, which promotes the production of graphic arts and videos based on Warlpiri ethnic aesthetics and cosmology. Michaels $(1987,1994)$ is a key scholar on native artistic production, and he focused his analysis on the social practices that surround it.

In several countries with indigenous populations, festivals of indigenous video and cinema have multiplied, as well as the institutions that support its production and distribution. An example of which could be the festival "Présence Autochtone" celebrated in Montreal or the "Native American Film and Video Festival" celebrated in New York. In these countries we can find an extensive professional production of native audiovisuals, or films dealing with indigenous issues, whether or not they have been made by indigenous directors. The idea of festivals has also been adopted in Latin American countries as well as within some documentary or independent cinema festivals where a special section on indigenous video and films has been created, as is the case of the festival "Contra el silencio, todas las voces", set in Mexico City. Festivals are a good source of funding and diffusion of the films, but, as Erica Wortham (2002) remarked, the selection committees have the power to classify and choose which works are relevant to be shown to the public, and, therefore, are a filter for the representation of the indigenous peoples. The existence of festivals or "special sections" is also a way of putting indigenous productions in a category apart from general cinema or amateur video.

Linked to the existence of these, and many other audiovisual initiatives, it is important to underline the importance of the global technology of the Internet. This medium can arrive through satellite to places where there are scarce communication media, like some isolated rural areas. On top of this, the Internet is the communication technology that is most difficult to control, which eases the broadcasting of video or radio channels that could be illegalized in a specific country, or that have an international audience, as is the case of the Chicano radios in California that broadcast for the homelands into rural areas in Mexico. Internet is the tool that indigenous groups use to communicate to foreign audiences and to other ethnic groups or social movements. Leuthold quoted Michaels (1987) reckoning that native cultures are local and theoretically linked with the territory they occupy and the mass media are necessarily concentrated and homogenising, whereas electronic media are omnipresent. Indigenousness navigates through cyberspace thanks to the wide spreading of Internet technology as well as because of the migrations of indigenous citizens all over the world. Indigenous cultures are constructed and represented through hypertext and social networking, and are then re-created in new ways through recognising and knowing other people and groups as similar, establishing links that could be difficult otherwise. The study of the indigenous presence on the Internet makes obvious the need for understanding the mediascape, i.e., the communications space that it occupies (García Canclini, 1995), going beyond the conceptualisation of indigenous groups based on their geographical territories.

21 The social movements that can be situated within the Indigenous Emergency have been clearly fostered by the existence of the technologies associated to cyberspace, which have allowed them to communicate their own images and demands widely and quickly. The Internet has been a major tool to situate most of the indigenous affairs in the world's political arena. According to Monasterios (2003), young indigenous Internet users are able 
to insert their points of view and cosmovisions within the global representations of Indigenousness, and thus transform the way in which indigenous peoples are most widely represented.

When talking about indigenous media it is imperative to mention the Video Nas Aldeias [Video in the Villages] project, an initiative born in Brazil during the 1990s, and which has achieved the aim to transfer technology and knowledge to certain indigenous groups so that they produce their own videos geared to their own interest. As aforementioned, some of the effects of this project were that different communities relatively isolated met each other through the circulation of videos, and found common points to demand their rights, and some of their films have been used as evidence in trials regarding land tenure. Indigenous video made in Brazil is also the object of study of the anthropologist Terence Turner (1991). The case of the Kakapo is relevant to illustrate the use of self-made videos as materials for advocacy and awareness raising, as they were used to inform some rural communities of the environmental exploitation of Brazilian Amazon basin, which was threatening their ways of living. Some videos shot by Kakapo cameramen were used as testimonials against processes such as the construction of dams. Their images were even used in trials that resulted in the cancellation of projects financed by the World Bank (Turner, 1992). Therefore, indigenous subjects took the tool of video and managed to be represented in an alternative way to that which the Brazilian State had reserved to them and that had been historically constructed.

From these experiences, the consciousness of the Kayapo and other activists regarding the power and the scope of their audiovisual witnessing has been increasing. Videos are ways to send messages to distant audiences, and they include messages elaborated from their own cosmology, but, obviously, using a strategic vision in terms of representation. With these videotapes and pixels travelling on the Net, cultural identities are also travelling; indigenous identities that are extremely politicised. They carry images that are read by audiences from all over the world not only as a source of information about realities that are often invisible, but also as ways of seeing that are pointing to other possible worlds.

\section{Indigenous media in Latin America: the State and its margins}

By analysing indigenous media in different areas we can realize how the projects that are, apparently, marginal in relation to the mainstream media and cultural policies have, in fact, a direct relation with governmental initiatives. Even though most indigenous media projects evolve and often are opposed to the communications status quo, we cannot avoid becoming conscious on how many of them have stemmed from initiatives from the State or from the Academy. The Latin American case is not an exception.

Besides the projects in Brazil that have already been mentioned, there is a regular indigenous media production in Mexico, Bolivia and Chile ${ }^{8}$.

In the case of Bolivia, the CEFREC (Centro de Formación y Realización Cinematográfica) is the institution of reference regarding the production and distribution of indigenous films. This independent centre depends on the Comité Audiovisual Indígena Boliviano (CAIB). Since 1996, the CEFREC is responsible for the promotion of the Plan Nacional Indigena Originario de Comunicación Audiovisual, which seeks to make all indigenous groups visible within the 
national space by promoting the self-representation of members of ethnic groups in Bolivia, which comprise $70 \%$ of the population, especially of those that are most marginalised.

In 1996 the CEFREC also signed, along with other organizations in the continent, a statement that wrapped up by saying "To preserve our cultures, to maintain our spirit in its essence: We demand the devolution of our image"'. Although this sentence could make us understand that they have an essentialist approach to Indigenousness, it is important to note that CEFREC and its productions are basically multi-cultural, and some of them are clearly protest-driven and innovative. This example is useful to understand the political aspect of visual discourses that may, apparently, seem mere artistic expressions from marginalized authors. The visual identity as other that they deliberately construct in some occasions helps to activate the processes of common identification, besides of a particular aesthetics that have consequences into action.

Before continuing with regional examples it is worth describing the development since the mid-1980s of the CLACPI, the Latin American Council of Cinema and Communication of the Indigenous Peoples, which was originally conceived by the CEFREC. This network is constituted of more than twenty-five organizations from different nations, and it works to coordinate the diffusion of local productions, as well as being a platform for debate, training and mutual empowerment. It is presented as a collective of people and groups, indigenous and non-indigenous, that articulates a discourse in favour of self-determination for "original indigenous peoples", as read on their website. By looking at its history we can see that the CLACPI was an initiative promoted at the beginning primarily by non-indigenous people, as Erica Wortham (2000) describes: "[The CLACPI was founded by] an international group of non-Indian Latin American anthropologists and filmmakers with a strong interest in ethnographic film about Indian peoples. Since then, the festival has been held in Brazil, Venezuela, Peru and Bolivia, forming an active network of CLACPI members along the way. (...) Over the years CLACPI has transformed itself into a loosely defined, open, umbrella organization with more indigenous members, but its headquarters remain in La Paz, Bolivia at the offices of CEFREC, the most active original member organization CEFREC is a non-profit organization that trains indigenous media makers and sponsors indigenous productions."

The main activity of the CLAPCI is the periodic celebration of the International Festival of Indigenous Peoples' Cinema and Video, held in a different country every two years. Parallel to this macro-event, with the participation of filmmakers from different origins, they organize local displays in the original countries and also outside Latin America. The first festival was celebrated in 1985 in Mexico City. The following was set in Rio de Janeiro on 1987 and coincided with the issue of two videographic projects that are now a reference on indigenous media, the ones we mentioned before: Video Nas Aldeias, led by the director Vincent Carelli; and the project with the Kakapo that was led by the photographer Mônica Frota and the anthropologist Terence Turner.

31 The following festivals, celebrated in Caracas (Venezuela, 1990), Lima and Cuzco (Peru, 1992), Santa Cruz (Bolivia, 1996), Quetzaltenango (Guatemala, 1999), Santiago (Chile, 2004), Oaxaca (Mexico, 2006), La Paz (Bolivia, 2008), Quito (Ecuador, 2010) and, scheduled, Bogotá and Medellin (Colombia, 2012), have become a meeting point and a place for the exhibition of works that are increasingly diverse and professionalized. They have also become a space for the reflection and discussion of the present and the future of indigenous media in the continent. 
To continue with the analysis of the national indigenous media situation, we turn to the case of Chile as described by Maria Paz Bajas (2008), who situates the beginning of Chilean indigenous video in 1994. The interesting feature of the Chilean experience is that it did not apparently arise from a governmental project. However, the Chilean natives had already appeared in several kinds of documentaries and, most specifically, in the film works of anthropologists. In 1999, two anthropologists led a particular media transference project in the region of Atacama, which resulted in a project called Lickanantay. Afterwards, the indigenous productions created by Mapuche and Aymara videomakers were the consequence of individual experiences of training and association with professional projects. The figure of the Mapuche filmmaker Jeannette Paillan is especially relevant because she has achieved a personal career as a professional director. Presently she has an important role within the CLAPCI's network.

\section{Indigenous video in Mexico}

The various programmes that connect audiovisual production and indigenous peoples in Mexico have a short history that begins in the 1970s and were related especially with the public policies of the so-called "participant indigenism", which, at the same time, were mirrored with pioneering initiatives in the richest countries such as Canada or Australia.

To situate the genealogy of indigenous media in Mexico, which is considered to be the Latin American country with the biggest and most stable indigenous video production, and also the origin of most films distributed all over the Latin American area, we should rewind a few decades to understand the link that these projects - now popular projects, have with governmental indigenist policies.

According to Wortham (2004), the involvement from the State in Mexican indigenous video is so wide that it could be considered as having a "national character" from the Instituto Nacional Indigenista (INI, the governmental agency that deals with indigenous issues, now called Comisión Nacional para el Desarrollo de los Pueblos Indígenas). The same author criticises (2000) the Mexican indigenous movies exhibited in the CLACPI festival in Quetzaltenango (1999), stating that they did not show the oppression that indigenous groups receive in many cases in the Mesoamerican country. Instead, they displayed the traditional lifestyles of the original peoples, contrasting with other American productions, which did bring out the violation of the most basic rights of indigenous groups all over the continent. The author attributes this tendency to the fact that the three indigenous videomakers that had their films screened (and that were awarded for their works) had been trained in the official Indigenous Video Centres in Oaxaca and Michoacan. Wortham adds that this de-politicisation is a common feature of Mexican indigenous video, except for the films created in the state of Chiapas.

In order to place this statement, we must go back to 1977, with the creation by the INI of the Audiovisual Ethnographic Archive (Archivo Etnográfico Audiovisual, AEA), considered to be the biggest collection of indigenous ethnographic documentaries existing in Mexico. This collection stems from the existence of several popular media in the country as well as in the southern countries, such as popular radios, which were the pioneering technology to serve interests and areas different from those covered by the mass media and the State media. Both radio and video could serve as tools of communication to overcome the barriers created by illiteracy and monolingualism in many regions. 

already a fact among popular groups, and this included indigenous groups. Leaders of indigenous organizations used very simple VHS camcorders to register life in the communities, as well as their organizational processes. According to one of the testimonials of this research from Oaxaca, at the beginning of the 1980s one indigenous leader from the area of Yalalag was gathering $16 \mathrm{~mm}$ movies from the foreign embassies in Mexico to show them to his peers. He himself filmed an election process during the 1980s, where full ballot boxes had been stolen. His recordings of this fact have been used for years as paradigmatic images to illustrate widespread electoral fraud in Mexico. In 1987 there was a workshop organized in Oaxaca by a filmmaker, Luis Lupone, specifically in the community of San Mateo del Mar. From that experience, an Ikood woman weaver called Teofila Palafox co-directed her first documentary entitled "'Weaving Wind and Sea" with the filmmaker. These are examples of how indigenous groups were already using cameras to their own profit at the time when the INI began to provide the AEA with content.

In 1989 the INI also set up the Programa de Transferencia de Medios Audiovisuales a Organizaciones y Comunidades Indígenas (TMA, Audiovisual Media Transfer to Indigenous Organizations and Communities Program), which was based on developing cinema workshops in various communities. As claimed by its founders, the TMA consisted in: “... the transfer of necessary devices for the realization of programs and registering, as well as of the teaching of knowledge that surrounds this medium. The intention is to provide the tools that allow [members of various indigenous organizations] producing works that respond to their own needs and interests. It is a priority to direct this transfer in a way that leads to the autonomy of the participant organizations and communities regarding contents, themes, and uses of their works." (Javier Sámano quoted by Ana Piño, 1995: 57).

From 1989 to 1994, the INI developed practical video workshops addressed to the members of indigenous communities and also for members of NGOs. After that, 36 organizations from all over Mexico were provided with basic infrastructure (camcorders, microphones and computers) to produce their own audiovisual works (Köhler, 2004). The resulting films accomplished the pursued goals of reinforcing the consciousness of the communities, and of becoming a way to communicate with the national society in shows organized in schools and institutions, in order to foster an inter-ethnic dialogue (Piño, 1995). Some other trainings and materials were also delivered to other organizations, but the INI lost contact with them and did not follow up their results.

In 1992, the Organización Mexicana de Videoastas Indígenas (OMVIAC, Indigenous Videomakers Mexican Organization) was created but could not develop further because of lack of funds and the large distances that separated most of the participating groups. Despite this, several local projects developed, even inter-state projects that linked producers from, for instance, Oaxaca, Guerrero, Chiapas and Tabasco. The INI set up some Indigenous Video Centres (CVI) under the TMA in Oaxaca, Michoacán, Sonora and Yucatán. In parallel, several independent videomakers continued working and developing autonomous projects interacting in different ways with the State.

41 The most relevant organization of indigenous videomaking nowadays is Ojo de Agua Comunicación, set in Oaxaca, in southeast Mexico. This project was born in 1998 after the dissolving of the CVI, which gave its participants a solid base regarding audiovisual resources and professionalization. However, they are suffering nowadays from the same problems that all other independent organisations suffer, and which were expressed on 
the final statements on the CLACPI's Festival in Chile: problems regarding the distribution of the movies and also problems linked with political and ideological autonomy in relation with national governments. Ojo de Agua plays a very active role in CLAPCI's activities, and it was in charge of the organization of the Festival in Oaxaca on 2006.

Moving South, as stated in the INI reports, up to 26 organizations were provided with audiovisual resources in Chiapas, but the materials were not updated at any point and the results were not reviewed. On top of that, Chiapas did not have its own Centro de Video Indigena, which had the aim of following up the implementation of the TMA. Regardless of this, some of the independent indigenous videomakers in Chiapas have been in contact and trained by people that came out of the CVI in Oaxaca, which gives another clear insight about the constant relation of the autonomous projects and the official projects.

The existence of the Centro Estatal de Lenguas, Artes y Literatura Indígenas (CELALI, State Centre of Indigenous Languages, Art and Literature) is the only piece left, although, of "official" indigenous videomaking in Chiapas. The department of media of the CELALI has generated over the last few years a huge archive documenting indigenous cultural expressions in Chiapas. They also produce media to teach local languages, and are responsible for a media station in some of these, such as Tseltal or Tsotsil.

Another key actor in understanding the audiovisual landscape in Chiapas, and in Mexico in general, is the Chiapas Media Project, locally known as Promedios (Promedios de Comunicación Comunitaria), which is considered to be one of the most relevant and consolidated projects in Latin America (Salazar and Córdova, 2008: 51). Promedios has worked with indigenous communities primarily linked to the Zapatista movement in Chiapas and the neighbouring state of Guerrero since 1998, to promote communication resources and autonomy. They provide training and materials, as well as funding from abroad and follow-up of the works of the local camarógrafos (cameramen). Their videos are registered mainly in order to have a record of internal important events as well as to have graphic witnesses of conflictive situations with governmental agents or policies. They also produce educational materials and awareness-raising videos either for internal and external audiences. Promedios has an important international network that allows them to have stable funding and distribution of films all over Europe, Latin America and the US.

Other projects have stemmed from the Chiapas Highlands, such as the Red de Comunicadores Boca de Polen. Since 2001, this autonomous organization has worked in several forms of communication media (video, radio and press), and has involved members of indigenous communities from various political and religious affiliations. Their aim is to promote the communication tools of these communities, putting an accent on impacting local audiences and with special attention on community cohesion. For instance, the trained communicators are always linked to their rural environments and they do not quit their other tasks (for instance, farming) to make their films, radio programmes, etc.

Another experimental project was witnessed by my own ethnographic experience ${ }^{10}$. It was the Proyecto Videoastas Indígenas de la Frontera Sur (PVIFS, Indigenous Videomakers from the Southern Border Project), which began in 1999 and lasted about nine years. Its specificity is that it was an academically driven proposal that came from anthropologists from two research centres (the Centro de Estudios Superiores sobre México y Centroamérica CESMECA - and the Centro de Investigación y Estudios Superiores en Antropología Social CIESAS -). Its promoters were aware of the importance of the demand for autonomous 
audiovisual media by the indigenous population of Chiapas, and wanted to set a space for training and research that would foster the creation of self-representation among members of indigenous organizations that were not covered by other networks, such as the Zapatista media. This project finished a few years ago after having released up to 30 videos, most of them of indigenous manufacturing, and some of them out of the collaboration between anthropologists and indigenous videomakers. Out of the experience of the PVIFS, some other projects and training spaces have generated, such as the Escuela de Cine y Video Mundos Inéditos, interacting with other local and international organizations and institutions. During its existence, the PVIFS provided a space of intercommunication and exchange among people from various origins and backgrounds, with diverse interests and styles. In the development of the project, some videomakers became professional and others acquired a new role within their organisations or communities. They all found themselves participating in debates among themselves or at home, or in their original communities, regarding their belonging and appropriateness as representatives of an indigenous identity, because they were mostly young migrants to the city. Their videos were a reflection of this: dealing with traditions that are endangered because they are only practiced by old people; with life in the city for someone who has to justify his or her background; with the dangers of damaging the natural environment or with the demands of the social movements that have local, national or global concerns.

Preparation of a cloth for the screening of a film in the site of a rural organisation

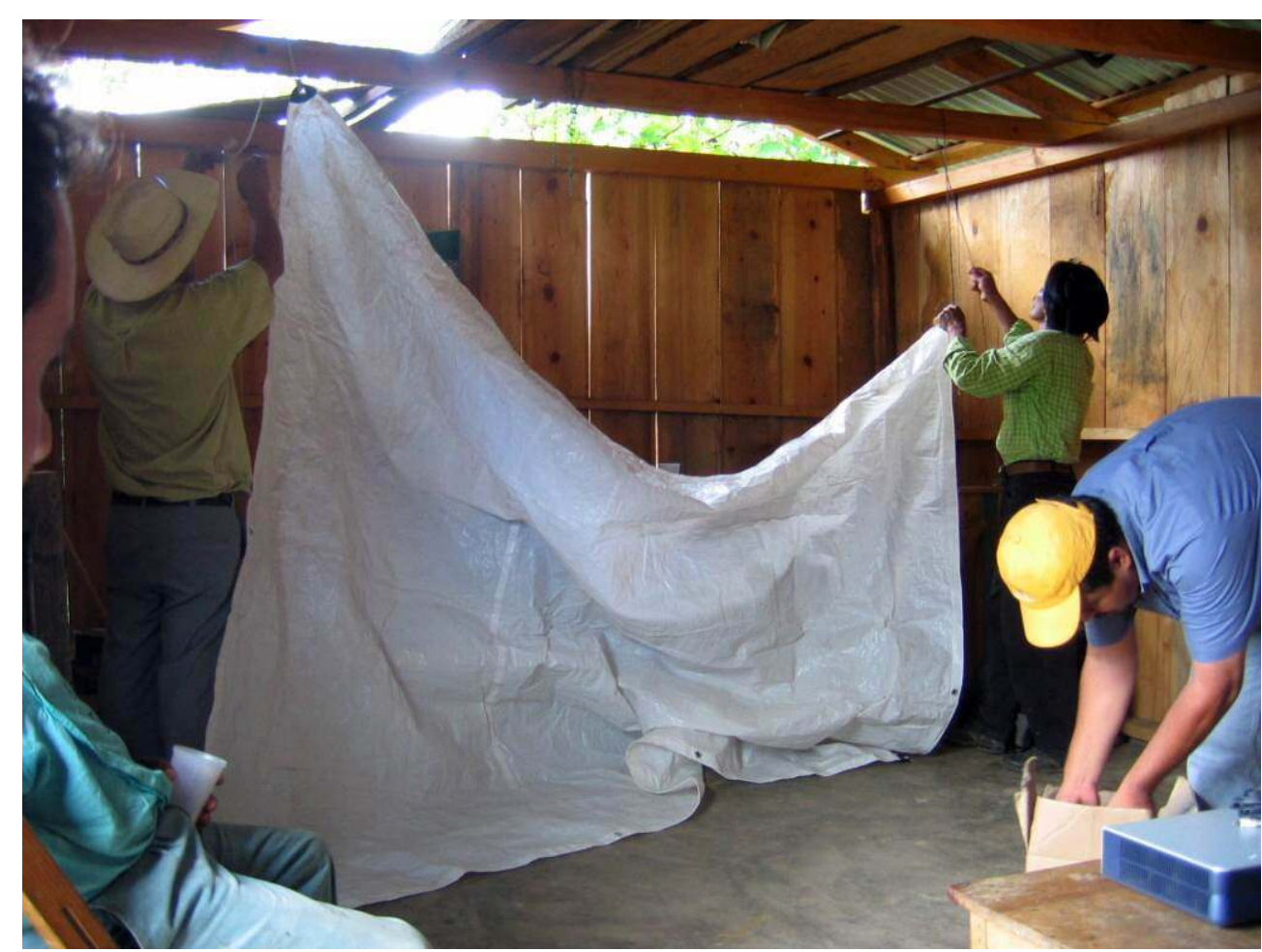

LAURA CARDÚs, 2006 


\section{Conclusion}

47 provide the Mexican nation with a honourable past, differentiated from the cultural
heritage that came with the Spanish colony. Indigenousness has inspired paintings, movies, even the architecture, during the $20^{\text {th }}$ Century, to justify the mestizo citizenship as the role model for the nation: the glorious pre-Hispanic past having been allegedly inherited by the mestizos of today. For this reason, the presence of images of the indigenous peoples of Mexico in mainstream media has been reserved to the most patronizing and folkloric clichés, while the actual Indians have been generally represented as hilarious rural bumpkins (see, as an example "El Ceniciento" by Gilberto Martínez Solares, 1951).

Thus, it is interesting to explore how the various ethnic groups have used the media when they had the opportunity and how, in fact, projects have evolved to generate alternative messages to those expected. The case of Chiapas is especially significant because it is a complex landscape that offers a scenario where the various actors that take diverse options converge: from the projects that are a natural evolution of the indigenist policies that begun on the 1970s, to the most radical autonomous projects that try to work in a totally independent way from the State and its resources. However, all these modalities meet in some points in relation to the visual discussion on ethnicity (meaning that there is not a special anti-essentialist discourse in videos stemming from alternative projects, as there is not necessarily always a traditional point of view about indianity in all the videos coming from institutionalised initiatives).

Nowadays it is difficult to foresee the future tendencies of indigenous video. In our hyperaudiovisualised world, all authors have all kinds of imprints, and indigenous videos made from the rural villages are influenced by Hollywood movies or by ethnographic cinema, whereas the filmmakers that are linked with the State institutions may be looking at the styles and messages from autonomous video experiences of alternative movements. As it has been already pointed out, the interesting thing that the films show is the concepts that are in discussion, not so much the political adscription or social situation of the persons and groups that are behind it.

My experience in watching and analysing visual productions made by videomakers from various kinds of organizations brings me to realise that the diversity and ubiquity of video projects exploded after the beginning of the $21^{\text {st }}$ century, which helped all kinds of audiences to know and observe the reality of contemporary indigenous peoples. After the second wave of the Indigenous Emergency (Bengoa, 2009), where the indigenous social movements were basically demanding the social participation of indigenous citizens as regular citizens, not within special categories or under special policies, the tendency of indigenous video projects has been to fuse with other kinds of actions from other movements. This, in my opinion, has resulted in the existence of more noticeably biased movies: ones more clearly political and more radically minded, making their claims observable; others explicitly using the folkorisation of traditions and identities, even the newly adopted ones.

51 It is imperative, though, to avoid analysing the productions made by the other in a simple way, as if they were mere responses to the portraits that have been made of the indigenous peoples and individuals within hegemonic discourses. Hegemonic and 
subaltern cultures (in a Gramscian sense) are in contact and exist because of their mutual feedback. The generation of images from subaltern groups necessarily needs to assume the hegemonic images that have been spread before, while the mainstream media absorbs discourses from independent media. It is common to see videos where the indigenous members of a group assume their identity as others, appropriating the portrait that has been made of them in mass mediated images. By representing themselves from otherness, they generate a message of understanding and incorporation of the messages made by their others. In doing so, they seize them and, in a way, neutralise them.

I have had the opportunity to watch the evolution in self-representation of young indigenous videomakers who began their career by using very stereotyping images of Indians (stressing the relation with nature and folklore, for instance) in order to find their place in a scenario where they were only appealed as being members of an indigenous community (not as being regular citizens with democratic rights and interesting things to explain by themselves). Afterwards, having been in touch with anthropologists and with diverse kinds of organisations (pan-indigenous movements, cultural collectives and virtual social networks), they began producing images of their realities with a more open and post-modern approach, representing their situation as one of those who are looking for a "New identity" in the global community. Recently, though, coinciding with the new wave of Indigenous Emergency and also with their entrance to adulthood, they have been using more strategic discourses in their films, presenting themselves as members an of indigenous community or organisation demanding equal rights as every other Mexican. This, in my opinion, makes a lucid example of how the video productions are directly related to the evolution of the State policies and the world political situation, and interact with them.

\section{BIBLIOGRAPHY}

BAJAS IRIZAR, María Paz (2008) “La cámara en las manos del otro. El estereotipo en el video mapuche" in Revista Chilena de Antropología Visual № 12 (pp. 70-102)

BENGOA, José (2000) La emergencia indígena en América Latina. Chile: Fondo de Cultura Económica

BENGOA, José (2009) "¿Una segunda etapa de la Emergencia Indígena en América Latina?" in Cuadernos de Antropología Social № 29 (pp. 7-22)

CARDÚS, Laura (2007) “El video indígena en la conformación de las identidades en el México contemporáneo, el caso de Chiapas" in Anuario CESMECA 2006. San Cristóbal de las Casas: CESMECA

CARDÚS, Laura (2009) "Sharing Video as a Cultural and Research Tool", texts of the International Jean Rouch Symposium, Paris. Online in http://antoine.chech.free.fr/textes-colloque-JR/ cardus.pdf

CUNNINGHAM, Stuart, Et. Al (2000) "Multicultural Broadcasting and Diasporic Video as Public Sphericules” in Americal Behavioral Scientist, Vol. 43, № 9 (pp. 1533-1547) 
GARCIA CANCLINI, Néstor (1995) Consumidores y ciudadanos. Conflictos multiculturales de la globalización. México: Grijalbo

GINSBURG, Faye (1991) “Indigenous Media: Faustian Contract or Global Village?” in Cultural Anthropology, № 6(1) (pp. 92-112)

HARLAN, Theresa (1999) “Adjusting the focus for an Indigenous Presence” in Carol SQUIERS (Ed.) OverExposed: Essays on Contemporary Photography. New York: The New Press.

KÖHLER, Axel (2004) "Nuestros antepasados no tenían cámaras: el video como machete y otros retos de la video-producción indígena en Chiapas, México" in Revista Chilena de Antropología Visual № 4

LEUTHOLD, Steven (1998) Indigenous Aesthetics. Native Art, Media and Identity. Austin: University of Texas Press

MONASTERIOS, Gloria (2003) "Usos de Internet por Organizaciones Indígenas de Abya Yala" in Comunicación, № 22. Caracas: Centro Gumilla de Estudios Venezolanos de Comunicación (pp. 60-69)

PROPIOS, Cristina (2002) "Vídeo indígena en México: viejas demandas, nuevos desafíos” in Raquel PIQUÉ \& Montserrat VENTURA (Eds.) América Latina. Historia y Sociedad. Una visión interdisciplinaria. Barcelona: Institut Català de Cooperació Iberoamericana (Amer \& Cat № 7)

RUSSELL, Catherine (1999) Experimental Ethnography. The Work of Film in the Age of Video. Durham \& London: Duke University Press

SALAZAR, Juan Francisco and Amalia CóRDOVA (2008) "Imperfect media and the poetics of indigenous video in Latin America" in WILSON, Pamela and Michelle STEWART (Eds.) (2008) Global Indigenous Media. Cultures, Poetics and Politics. Durham and London: Duke University Press (pp. 39-57)

SPITULNIK, Debra (1993) “Anthropology and the Mass Media” in Annual Review of Anthropology № 22 (pp. 293-315)

TURNER, Terence (1991) “The Social Dynamics of Video Media in an Indigenous Society: The Cultural Meaning and the Personal Politics of Video-Making in Kayapo Communities" in Visual Anthropology Review № 7(2) (pp. 68 - 76)

TURNER, Terence (1992) “Defiant Images: The Kayapo Appropriation of Video" in Anthropology Today Vol. 8, № 6 (pp. 5-16)

WILSON, Pamela and Michelle STEWART (Eds.)(2008) Global Indigenous Media. Cultures, Poetics and Politics. Durham and London: Duke University Press

WORTH, Sol and John ADAIR (1997) [1972] Through the Navajo Eyes. An Exploration in Film Communication and Anthropology. Albuquerque: University of New Mexico Press

WORTHAM, Erica (2000) “Building indigenous video in Guatemala” in Jump Cut № 43 (pp. 116-119) WORTHAM, Erica (2005) “Más allá de la hibridad: Los medios televisivos y la producción de identidades indígenas en Oaxaca, México” in Liminar. Estudios Sociales y Humanísticos Vol. III № 2 (pp. 34-47) 


\section{NOTES}

1. This concept is taken from the Spanish "Indigenista", referring to all official policies and theories that involve indigenous groups within Latin American states.

2. Latin American Council of Cinema and Communication of the Indigenous Peoples

3. Original in Spanish, from http://www.clacpi.org

4. See http://www.igwia.org

5. Discourses about indigenous peoples and ethnicity built from official institutions within the State, encompassed with certain policies and theoretical backgrounds.

6. As an example, this link: http://www.nativenetworks.si.edu/eng/rose/cefrec.htm\#open includes the whole declaration after the festival held in 1996 in Bolivia.

7. Which was based on a fieldwork where I could accompany several videomakers linked to various projects that will be described below. I focused on collaboration with a specific group of young videomakers of rural origin and in their processes of decision-making, recording, editing and screening their works locally.

8. Without forgetting productions made in Ecuador and Peru, for instance, which are not dealt with in this text.

9. Extract from the "Open letter from Cochabamba", signed by all the participants of the Indigenous Forum in the 5th Festival of Video and Cinema of the Indigenous Peoples. Original in Spanish.

10. For more details on this project and the research I conducted within it from 2005 to 2007 see Cardus (2007, 2009) and http://sureste.ciesas.edu.mx/Investigacion/Proyectos\%20especiales/ Proyectos/PVIFS/ingles/pvifs.html

\section{ABSTRACTS}

Media produced and featured by members of so-called indigenous communities present an excellent field to observe the phenomena defined by José Bengoa as "Indigenous Emergency" $(2000,2009)$, as well as of the mise en scène of the processes of ethnic identification. This article overviews various experiences of audiovisual media production in Brazil, Chile, Bolivia and puts an accent on the example of Mexico. The existing literature on indigenous media has portrayed films made by indigenous people in Mexico as products of governmental participatory policies. In spite of that, this article, based on fieldwork research developed in southeast Mexico, gathers experiences and examples from autonomous projects that defy the definitions of the ethnical structure of the State constructed by several indigenist policies during the recent history of Mexico.

Les productions audio visuelles produites et créées par les membres des communautés labélisées "communautés indigènes ou communautés autochtones " offrent un champ d'étude particulièrement intéressant pour observer tant le phénomène défini par José Bengoa comme «Intervention d'urgence indigène" (200-2009), que la mise en scène des processus d'identification ethnique. Cet article aborde différentes expériences de production audio visuelles qui ont eu lieu au Brésil, au Chili, en Bolivie, et s'attarde plus particulièrement à 
l'exemple de Mexico. La littérature existante sur les "medias autochtones » décrit les films produits par les communautés autochtones comme des productions soutenant la politique gouvernementale. Malgré cela, cette étude, qui s'appuie sur des recherches menées sur le terrain, au Sud Est de Mexico, retrace différentes expériences et exemples issus de projets autonomes qui remettent en cause les définitions des structures ethniques de l'état, construites par des politiques indigénistes mises en place dernièrement.

Las producciones audiovisuales producidas por miembros de las llamadas "comunidades indígenas" constituyen un excelente campo de observación del fenómeno que José Bengoa (2000, 2009) definió como "emergencia indígena", así como de la puesta en escena de los procesos de identificación étnica. Este artículo repasa varias experiencias de producciones audiovisuales en Brasil, Chile, Bolivia, poniendo el acento en el caso de México. La literatura existente sobre las media indígenas ha categorizado las películas realizadas por los indígenas en México como resultado de las políticas de participación gubernamental. En vez de adoptar esta perspectiva, este artículo, basado en un trabajo de campo desarrollado en el sureste de México, reúne experiencias y ejemplos de proyectos autónomos que ponen en cuestión las definiciones de la estructura étnicas del Estado construidas por representantes de las políticas indigenistas de la historia reciente de México.

INDEX

Keywords: indigenous peoples, Latin America, video, cinema, media, ethnicity

Palabras claves: Pueblos Autóctonos, América Latina, Video, Cine, Media, Etnicidad

Mots-clés: populations autochtones, Amérique latine, vidéo, cinéma, media, ethnicité

\section{AUTHOR}

\section{LAURA CARDÚS I FONT}

Universitat de Barcelona (UB) 